\section{Multicentric and multifocal breast cancer diagnostics (review and portfolio)}

\author{
V.F. Zavizion', F.I. Kulikova ${ }^{2}$, \\ Davlietova $^{1,2}$
}

Dnipropetrovsk State Medical Academy of the Ministry of Health of Ukraine ${ }^{1}$, Dnipro

Dnipro Medical Institution of Traditional and Nontraditional Medicine ${ }^{2}$, Dnipro
According to the National Cancer Register of Ukraine, the total number of patients with newly diagnosed breast cancer in 2014 was 13,641 women, in $2015-14,332$, in $2016-14,406$ women and in $2017-14,402$ women. At routine examinations were identified $-50.0 \%, 47.6$ $\%, 45.4 \%$ and $43.9 \%$, respectively. The total number of deaths is $5874,5863,5851$ and 5640 , respectively [4]. This statistics, of course, indicates the necessity to improve screening technologies and clarifying preoperative diagnostics of breast cancer.

Breast cancer in (42-48) \% of cases is a multicentric or multifocal process $[5,16]$. Multicentricity of the tumor is the presence of several tumor foci located in different quadrants (segments) of the breast; multifocality is the presence of several tumor foci in one square or segment.

Multifocal and multicentric cancers evidently are biologically different diseases [16]. Multicentric cancer is more aggressive than multifocal and unifocal, and is more often associated with a younger age and larger tumor size, and is also an independent predictor of metastasis to the lymph nodes.

The importance of identifying all the foci is that with a multicentric lesion, more radical types of surgical treatment are applied. With cancer monocentricity, organ-preserving surgery is predominantly chosen, and with multicentricity - radical mastectomy [10]. Multifocality not detected at the preoperative stage and, especially, multicentricity is the cause of relapses in more than $40 \%$ of cases [6].

Multifocal and multicentric cancers are included in the syndrome of non-palpable breast formations, characterized by the absence of clinical manifestations and palpation findings, combining diseases of a benign and malignant nature, requiring a special diagnostic approach [8]. Therefore, all suspicious lesions $[1,2,6,7,16]$ should be identified before the operation as part of a clarifying diagnostics.

In common radiology, problem-oriented studies of multicentric breast cancer are practically absent. The fundamental works describe the semiotics of monofocal breast cancer, multicentric cancer is relatively detailed presented only in the works $[8,9,11-13]$. To a certain extent, this is due to the usually limited set of diagnostic equipment in various institutions.

The purpose of the review is to consider the information content and effectiveness of radiation diagnostic technologies in the aspect of identification of multicentric and multifocal breast cancer.

The history of the breast diseases visualization development began in 1913 by the professor of medicine and the member of the Berlin Academy of Sciences A. Salomon (1883-1976), who studied the effect of $\mathrm{x}$-ray radiation on breast tissue, applying for this purpose mastectomy samples [24]. He was the first to describe tumor nodes, their difference from benign formations, multicentric variant of tumor growth, tumor microcalcifications [9].

With clinical examination and $\mathrm{x}$-ray mammography, more than $90 \%$ of patients only monocentric neoplasms are diagnosed $[8,9]$.

At palpation of the breast in 149 of $200(74.5 \%)$ patients only 1 tumor node is identified, in 43 $(21.5 \%)-2$ nodes, in $8(4.0 \%)-3$ nodes. Thus, a clinical examination in $74.5 \%$ of patients incorrectly evaluates the prevalence of the malignant process. This is due to the small size of additional tumor nodes, concomitant fibrocystic mastopathy, which creates a dense background, masking the tumor nodes $[8,9]$.

X-ray mammography does not solve the problem of reliable detection of pathology in the 
so-called "dense breast" - in cases of severe fibrosis due to the summation effect, the diagnosis of focal and diffuse formations is more difficult. The summation effect can be reduced by linear tomosynthesis, but this method leads to a greater radiation dose than at linear $\mathrm{x}$-ray mammography, and is less accessible due to the high cost of the apparatus [8-10].

Mammography is considered as the main method for diagnostics of breast tumors. However, its accuracy is significantly reduced when diagnosing changes in the dense tissues of the breast, especially when detecting minimal breast cancer $[8$, $10]$ and breast cancer multicentric forms $[9,10]$.

The digital mammography + digital tomosynthesis algorithm for the diagnosis of multicentric cancer in patients with loose breast provides a higher sensitivity than digital mammography ( $p$ $=0.002[23]$.
It was demonstrated that contrast mammography is comparable in sensitivity to MRI, but is more effective in detecting multicentric lesions of the breast $[15,18]$.

Mammoscintigraphy. In women with multicentric breast cancer, detected against a background of low X-ray density of breast tissue $(\mathrm{A}+\mathrm{B}$ type), the combination of digital mammography and mammoscintigraphy provides sensitivity $(92.7 \%)$ higher $(p<0.001)$, than mammoscintigraphy $(82.9 \%)$ and digital mammography (43.9 $\%$ ), against the background of increased X-ray density of the breast tissue $(\mathrm{C}+\mathrm{D}$ type), the combination of digital mammography and mammoscintigraphy has a sensitivity of $100 \%$, specificity of $97.2 \%$ and overall accuracy of $97.3 \%$ [13] (Fig. 1). Mammoscintigraphy was performed in planar mode on "Forte (Philips)" emission computer tomograph with two rectangular detectors.

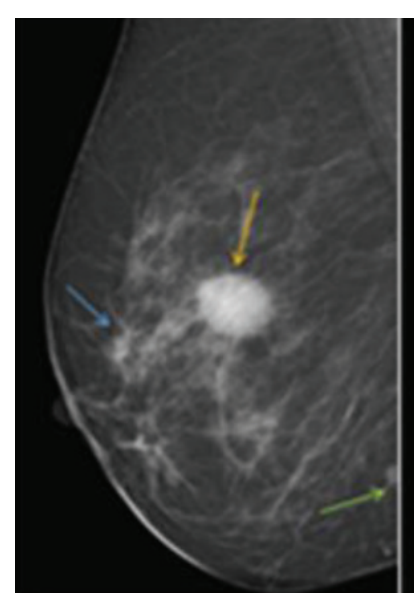

A

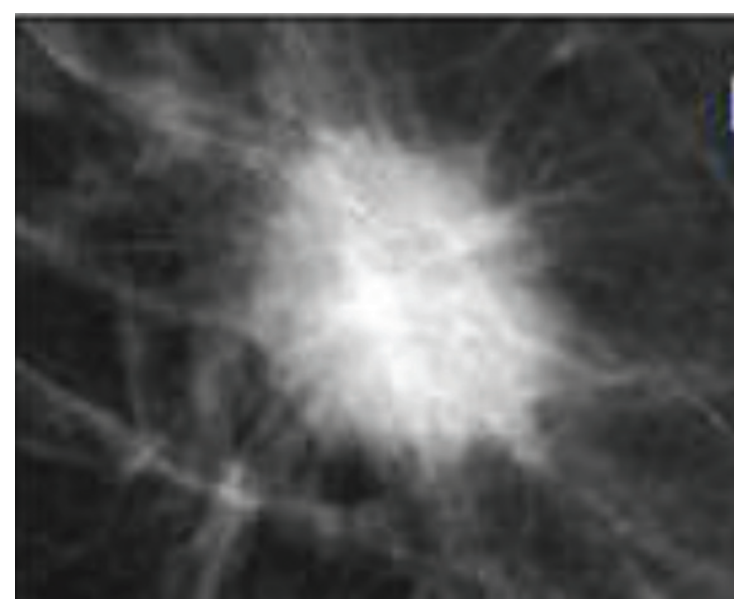

D

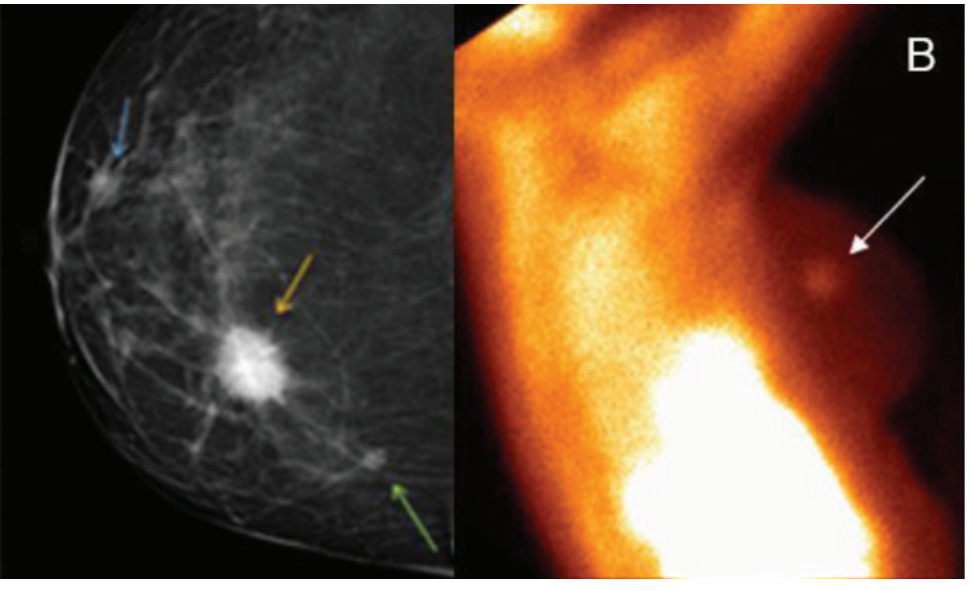

C

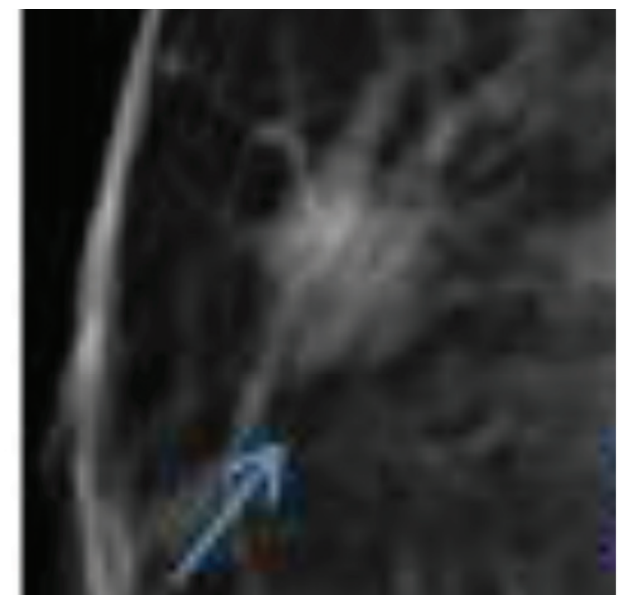

$\mathbf{E}$

Fig. 1. Patient H., 60 years. Palpable lesion focus of the right breast. A-mammogram, MLP, Bmammogram, CP, C-mammoscintigram, D, E-mammograms [13]. 
On mammograms in mediolateral projection (MLP) (A) and craniocaudal projection (CC) (B) in the right gland against the background of involutive changes (A-type of breast density according to ACR), 2 nodular formations $(C, D)$ with radiant indistinct contours $22 \mathrm{~mm}$ in diameter and $7 \times 6 \mathrm{~mm}^{2}$ are detected. The third node with clear uneven contours (E) (indicated by a green arrow) $5 \mathrm{~mm}$ in diameter. BI-RADS 5 cancer of the right gland (multicentric form). Fragment of the patient's multiscintigram in lateral projection with ${ }^{99 \mathrm{~m}} \mathrm{Tc}$-technetril: in the right breast, the focus of pathological hyperfixation of radiopharmaceuticals up to $22 \times 28 \mathrm{~mm}^{2}$ (white arrow) is detected. Axillary lymph nodes and skin are not changed. Morphological verification - invasive ductal carcinoma (multicentric growth) [13].

Full-format digital x-ray mammography has been proposed for women with focal changes in the breast of 40 years and older after the elimination of acute inflammatory manifestations to exclude a multicentric or synchronous process in mastitis-like cancer [2].
Sonography. A known technique for tumor marking under aseptic conditions, under local anesthesia and ultrasound control [10]. With multicentricity, it is desirable to label each tumor site. After labeling the carcinoma, mammographic control is recommended. Ultrasound (US) is effective in recognizing X-ray negative lobular breast carcinoma, but with multicentric and bilateral tumor spread characteristic for lobular breast carcinoma, the effectiveness of US is reduced [17, 22, 25].

The examination protocols of 122 patients with multicentric breast cancer were analyzed. Tumor lesions were detected in the form of hyperechoic zones of rounded shape with uneven contours. The conclusion of the multicentric nature of tumor growth was made in 50 patients $(41.0 \%)$. When comparing the results of US and mammography, the coincidence of diagnoses was established in $33(27.0 \%)$ patients [1].

In the study [1], multicentric breast cancer was visualized with sonoelastography (Fig. 2).

Magnetic resonance imaging. MR mammography with dynamic contrasting is a highly infor-

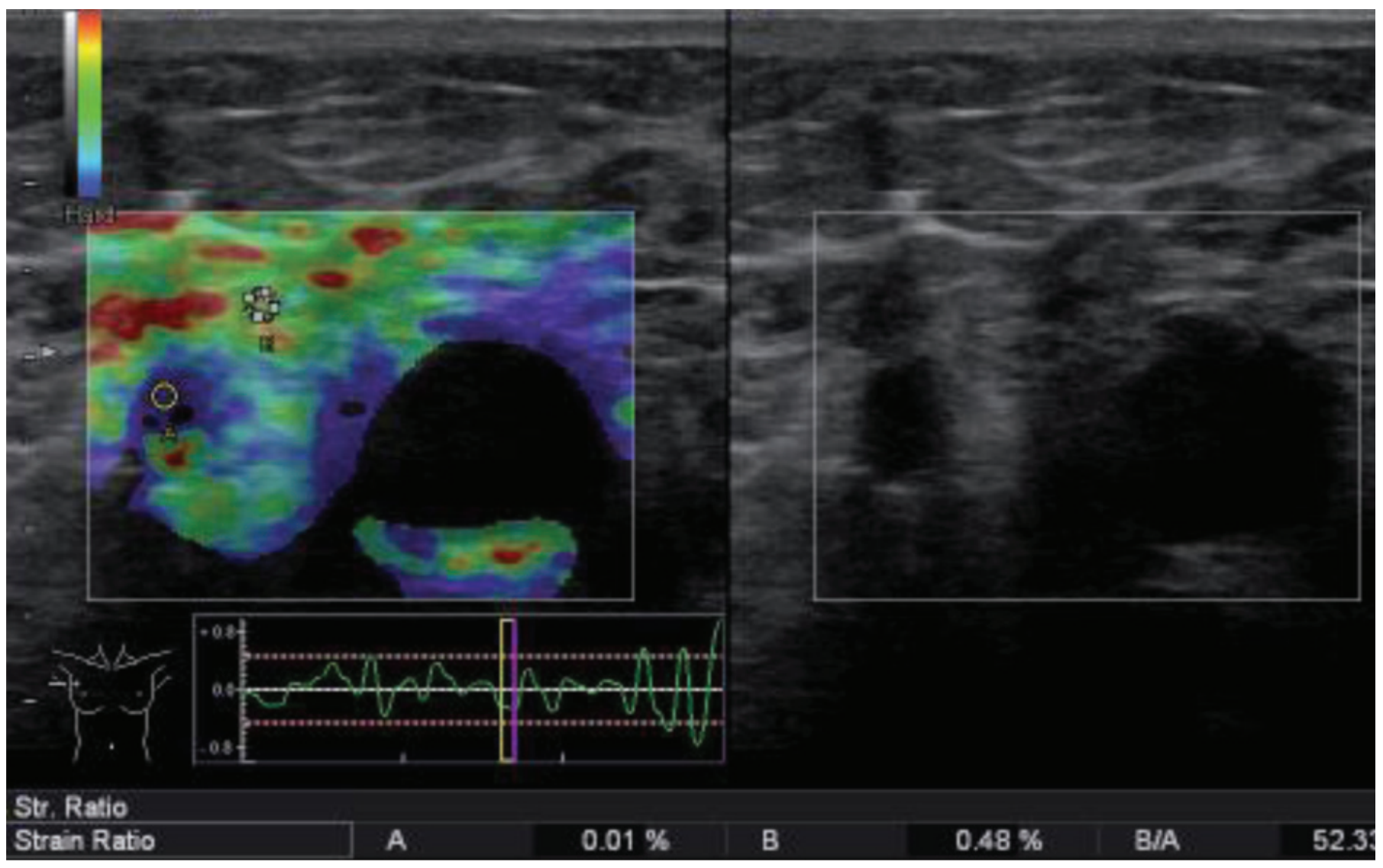

Fig. 2. Sonoelastogram of multicentric breast cancer [12]. 
mative diagnostic method of breast tumors. The method allows to evaluate the structure and degree of neoplasms' vascularization, conduct differential diagnostics, identify the multifocal and multicentric nature of the lesion, the degree of prevalence of the process $[3,11]$. In this study, up to $80 \%$ of all focuses are determined (Fig. 3, 4 ), that significantly exceeds the capabilities of traditional mammography.

It is considered that MR mammography is superior to mammography and US in determining the size of the tumor, unifocal, multifocal, multicentric and contralateral growth [20].

Of all cases of multicentricity and multifocality, the additional mammography occult foci are detected in 6-34 \% of patients at MRI, that leads to a change in primary tactics in $19.4 \%$ of cases [21].

Multispiral computed tomography allows to uniquely interpret the nature of the tumor growth and spread: multicentric and multifocal (Fig. 5). Reliable signs were obtained only with contrast: peak contrast in the venous phase $(100$ $\%$ ), doubling densitometric indicators in the affected area $(100 \%)$.

The multicentric breast lesion detection rate at mammography is $48.1 \%$, at US $-31.6 \%$. The effectiveness of preoperative diagnosis of multicentric breast cancer of stage I does not exceed $38.2 \%[5]$.

A large tumor node in multicentric breast cancer is most often ( $74.4 \%$ of cases) localized in the upper outer quadrant. The second and third tumor nodes are more often found in the upper-outer quadrant (46.7\% and $41.6 \%$, respectively), their histological structure in most cases is similar to a large node. The most common morphological form in multicentric breast cancer is infiltrative duct cancer [5].

Infrared thermography, according to [14], is a highly sensitive method for detecting multifocal multicentric breast carcinoma when applying thermograms' post-processing programs.

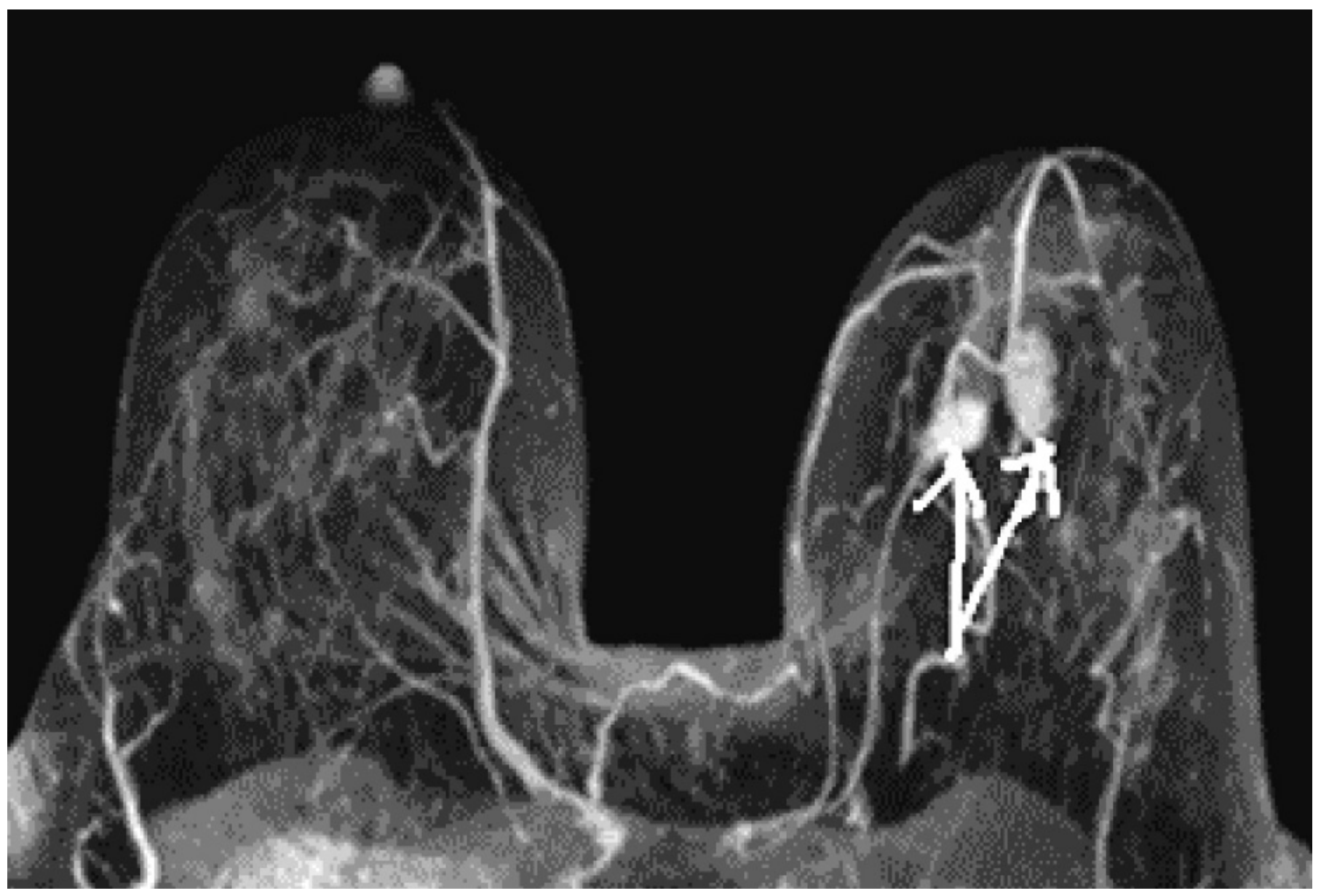

Fig. 3. MR mammography. Contrast $T_{1} V I$, multifocal cancer consisting of two nodes is visualized in the left breast - indicated by arrows, histologically - invasive lobular carcinoma [7]. 


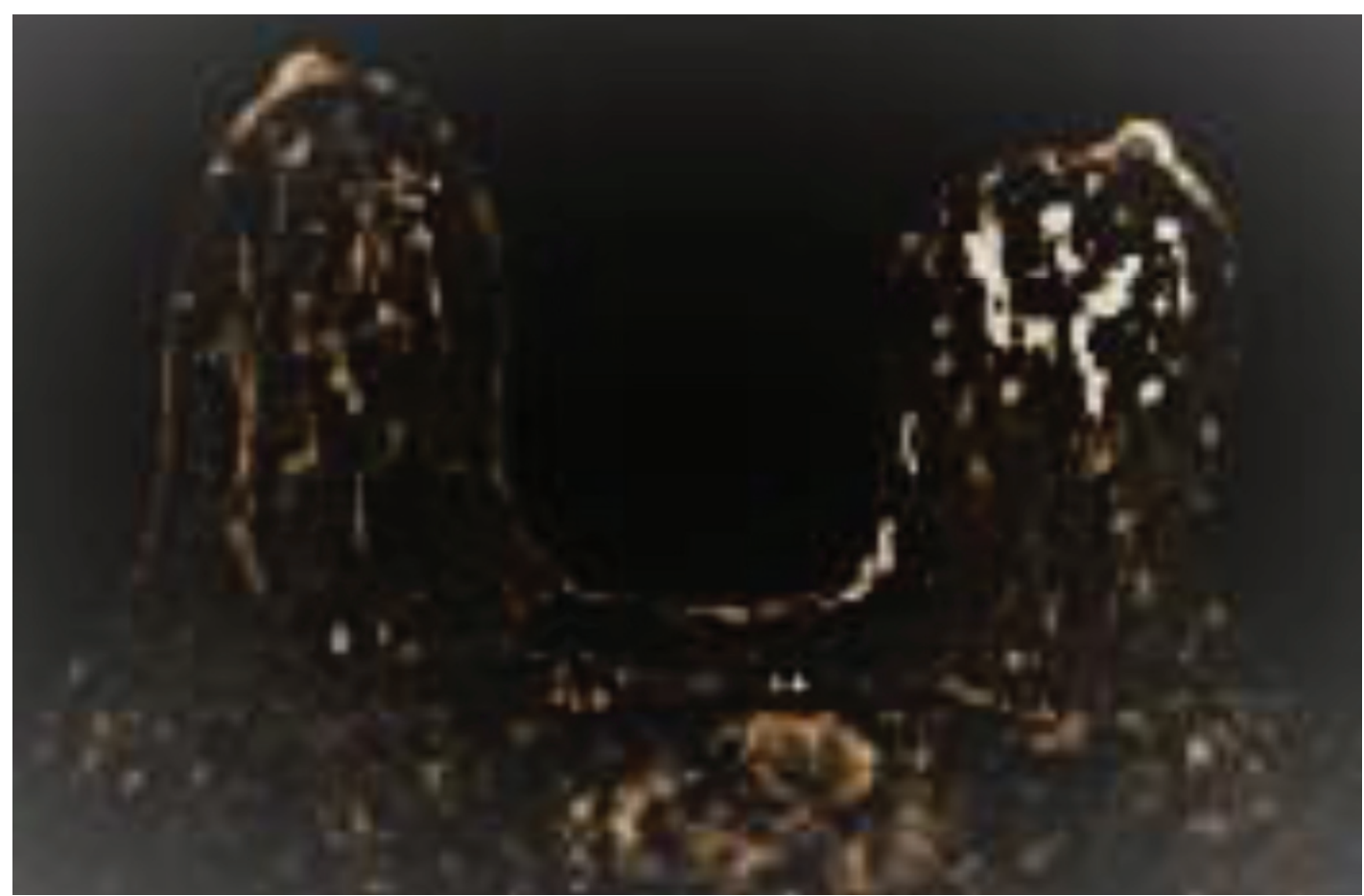

Fig. 4. MR mammography. $T_{1} V I$ with contrast, in the left breast-multicentric cancer (authors' portfolio).

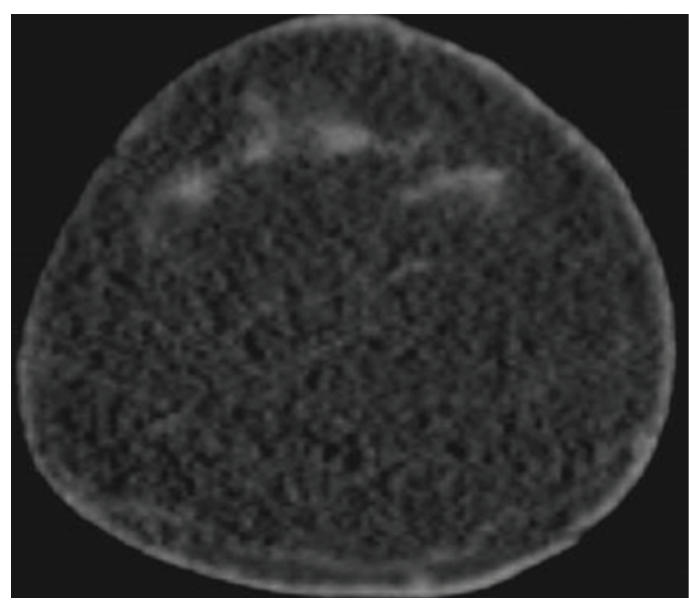

A

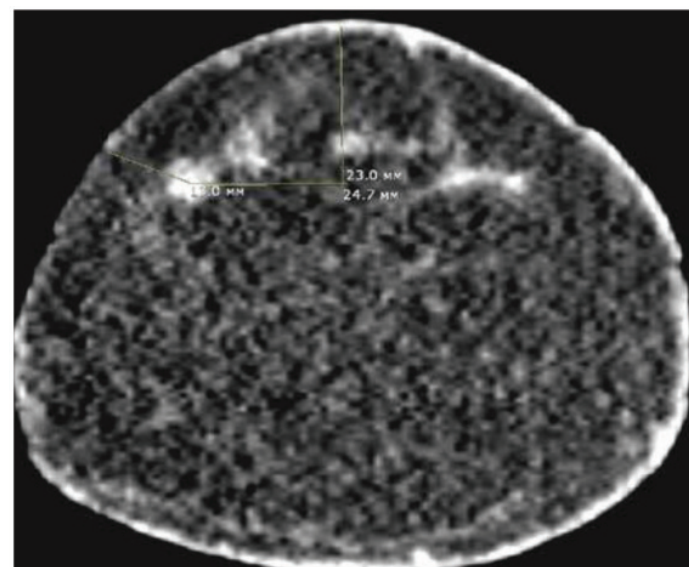

C

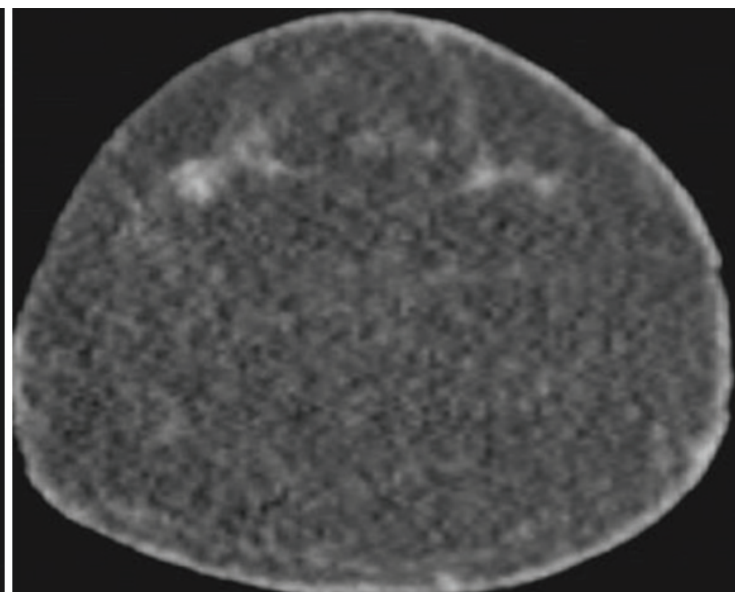

B

Fig. 5. MSCT - MG. Left breast cancer. The upper-outer quadrant - heterogeneous lesions of $8 \times 6 \mathrm{~mm}^{2}$ with fuzzy contours, density up to 26 units $X(A)$, accumulating contrast medium up to 68 units $X$ in the arterial $(B)$ and especially in the venous (C) phases with a feeding vessel and an actively contrast accumulating intramammary lymph node of $6 \times 6 \mathrm{~mm}^{2}$ in the Zorgius zone [8]. 


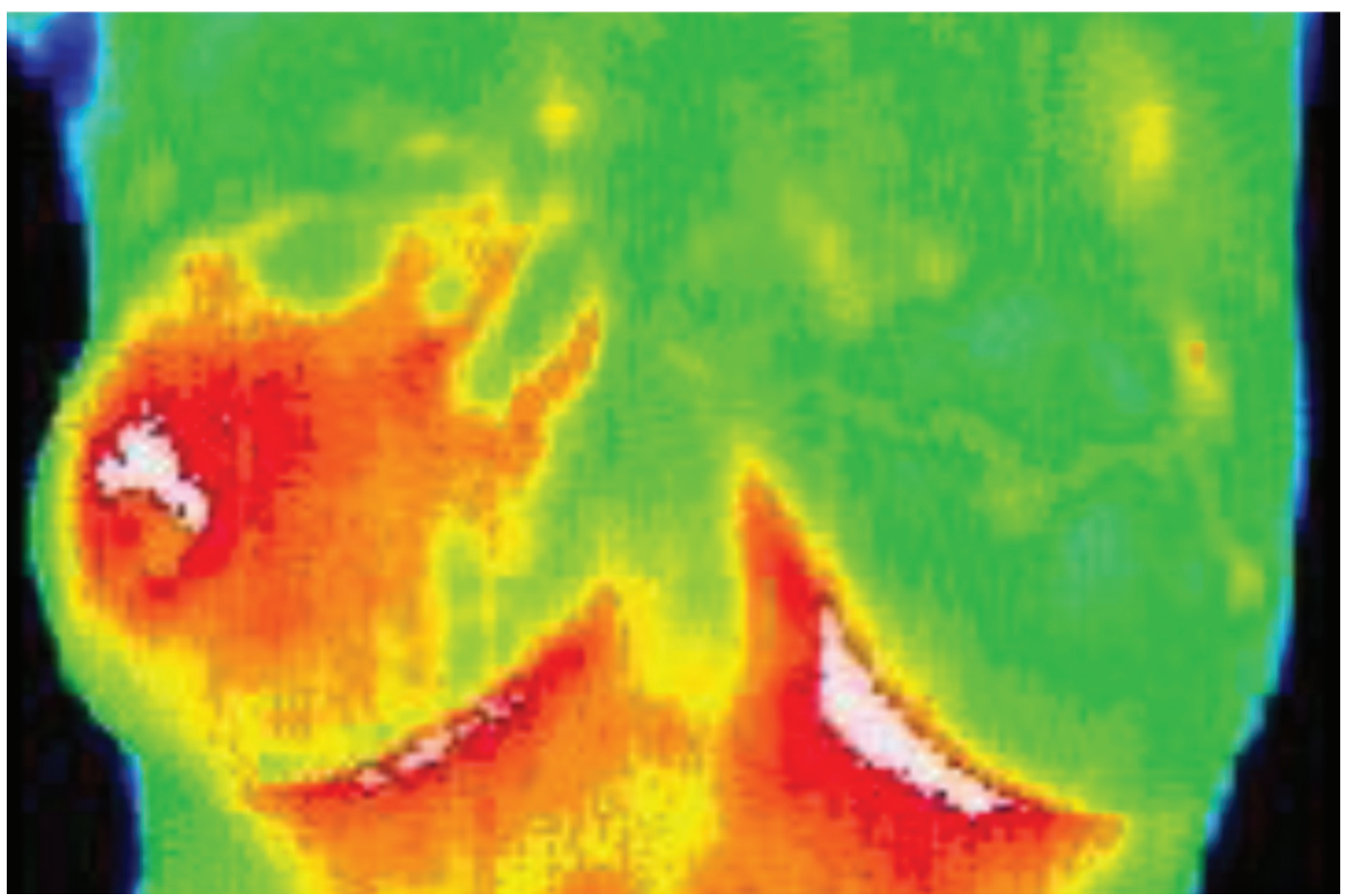

Fig. 6. Patient Shch., 49 years. Infrared thermography. Right breast multicentric cancer (authors' portfolio).

Electric impedance mammography $[16$, 20]. The electrical conductivity of the breast malignant tumors is different from the electrical conductivity of healthy tissues. The physical basis of the electric impedance mammography method is injection of electrical impulses into the field of investigation and fixing the distribution of electrical potentials on the breast skin surface. Changes in the electrical conductivity are displayed in reconstructed electrical impedance images, where cancer foci with abnormal electrical conductivity can be detected (Fig. 7). Advantage of the technology: examination safety (in comparison with X-ray mammography and X-ray computed tomography), low cost equipment, possibility of multiple examinations of one patient during screening, treatment and monitoring.

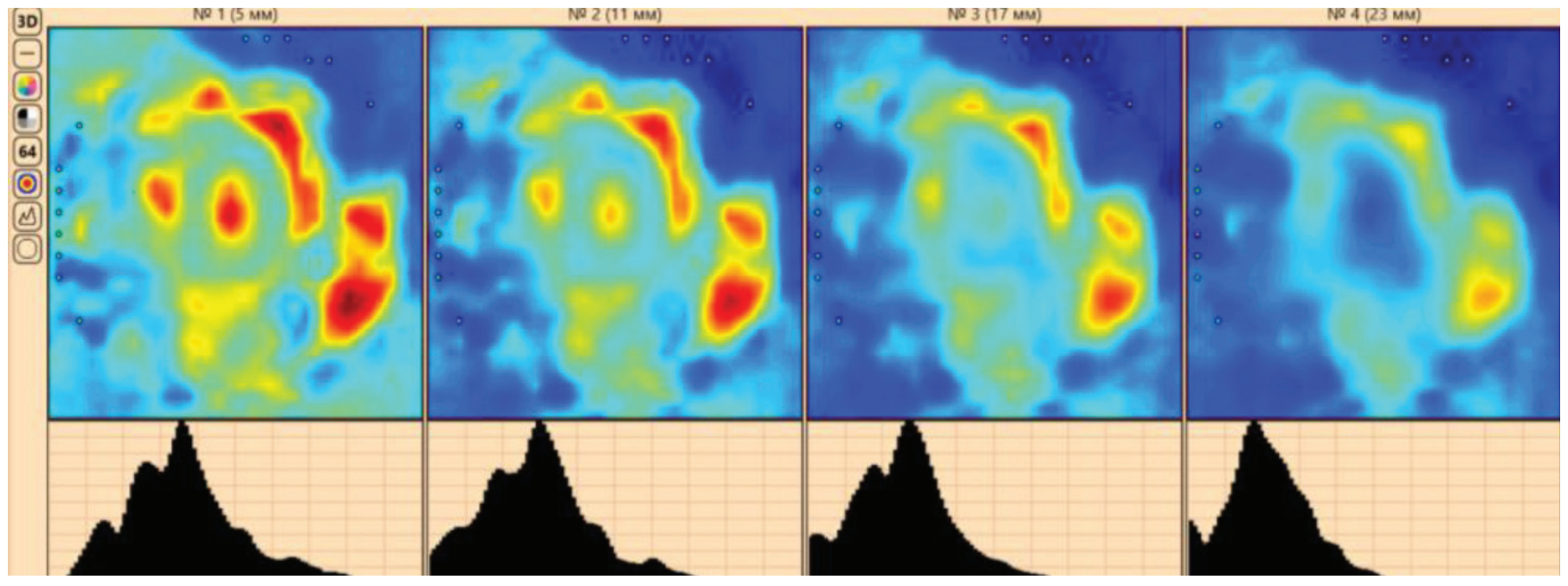

Fig. 7. Patient Ch., 45 years. Electric impedance mammography. Slices $-6 \mathrm{~mm}$. Right breast multicentric cancer (authors 'portfolio). 
A certain resource for improving the diagnostic effectiveness for multifocal/multicentric cancer is associated with studies on the information content of a fundamentally new transmission optical tomography [19].

\section{Conclusion}

Multicentric breast cancer was described for the first time more than 100 years ago precisely thanks to the first medical imaging technology. For common radiology, the problem of the identification definition of multifocal/multicentric breast cancer information content and diagnostic effectiveness as part of high-tech medical imaging technologies remains actual.

The authors declare no conflict of interest.

\section{Literature}

1. Аблицова Н. В. Лечебная тактика при первично-множественном раке молочной железы: дис. ... канд. мед. наук: 14.00.14 / Наталья Валерьевна Аблицова; [Московский научно-исследовательский онкологический институт]. - М., 2009. - 133 с.

2. Аксьонова О. Г. Променева діагностика запальних захворювань грудної залози: дис. ... канд. мед. наук: 14.01.23/ Олена Геннадіївна Аксьонова; [Нац. мед. акад. післядиплом. освіти ім. П. Л. Шупика]. Київ, 2015. - 200 с.

3. Злоякісні новоутворення молочної залози // Бюл. Нац. канцер-реєстру. - № 20. Рак в Україні, 2017-2018. - С. 46-47.

4. Зернов Д. И. Возможности магнитнорезонансной маммографии в диагностике рака молочной железы: дис. ... канд. мед. наук: 14.01.12 / Дмитрий Игоревич Зернов; [Российский онкологический научный центр РАМН]. - М., 2010. - 95 с.

5. Кириллова Е. Л. Мультицентрический рак молочной железы: оптимизация диагностики и хирургического лечения: дис. ... канд. мед. наук: 14.01.17, 14.01.12 / Елена Леонидовна Кириллова; [Научный центр лазерной медицины]. - М., 2014. - 146 с.

6. Комяхов А. В. Оценка эффективности неоадъювантной системной терапии рака молочной железы с помощью магнитно-ре- зонансной томографии и сонографии: дис. ... канд. мед. наук: 14.01.12 / Александр Валерьевич Комяхов; [НИИ онкологии им. Н.Н. Петрова]. - Санкт-Петербург, 2016. $136 \mathrm{c}$.

7. Меладзе Н. В. Роль магнитно-резонансной спектроскопии в комплексной диагностике опухолей молочной железы: дис. ... канд. мед. наук: 14.01.13 / Нино Вахтанговна Меладзе; Московская медицинская академия. - М., 2013. - 120 с.

8. Новикова Е. В. Комплексная лучевая диагностика непальпируемых образований молочных желез в пременопаузальном периоде: дис. ... канд. мед. наук: 14.01.13 / Елена Васильевна Новикова; [1-й медицинский университет им. И.М. Сеченова]. - М., 2018. $-200 \mathrm{c}$.

9. Оксанчук Е. А. Двуэнергетическая контрастная спектральная маммография (CESM) в диагностике непальпируемых образований молочной железы с высокой плотностью тканей: дис. ... канд. мед. наук: 14.01.13 / Елена Александровна Оксанчук; [Рос. научный центр рентгенорадиологии M3 РФ]. - М., 2017. - 144 c.

10.Павликова О. А. Эффективность предоперационной лекарственной терапии первично-операбельного рака молочной железы: дис. ... канд. мед. наук: 14.01.12 / Ольга Аркадьевна Павликова; [Национальный медицинский исследовательский центр онкологии им. Н.Н. Блохина]. - М., 2019. - 152 с.

11.Подберезина Ю. Л. МР-маммография в планировании объема хирургического лечения рака молочной железы: дис. ... канд. мед. наук: 14.01.13 / Юлия Львовна Подберезина; [Российская медицинская академия последипломного образования]. - М., 2011. $-88 \mathrm{c}$.

12.Соловьев В. И. Соноэластография центральное новое звено в предоперационном алгоритме у пациенток с подозрением на злокачественные новообразования молочных желез / В. И. Соловьев, А. В. Борсуков, М. А. Сафонова // Уч. записки Орловского ун-та. - 2014. - №3 (59). - С. 259-262.

13. Черная А. В. Сравнительный анализ информативности цифровой маммографии и маммосцинтиграфии в диагностике рака молочной железы: дис. ... канд. мед. наук: 14.01 .12 / Антонина Викторовна Черная; 
[Национальный медицинский исследовательский центр онкологии им. Н.Н. Петрова]. -2018 . - 112 с.

14. Antonini S. Thermographic visualization of multicentric breast carcinoma/ S. Antonini, D. Kolarić, Ž. Herceg // 2015 57th International Symposium ELMAR (ELMAR). - Zadar, 2015. - P. 13-16. https://doi.org/10.1109/ ELMAR.2015.7334484.

15.Blum K. S. Use of contrast-enhanced spectral mammography for intramammory cancer staging / K. S. Blum // Acad Radiol. - 2014. - Vol. 21(11). - P. 1363-1369. doi: 10.1016/j.acra.2014.06.012.

16. Characteristics of Multifocal and Multicentric Breast Cancers/ P.1.Kanumuri, B. Hayse, B.K. Killelea [ et al.] // Ann Surg Oncol. - 2015. - Vol. 22(8). - P. 2475-2482. doi: 10.1245/s10434-015-4430-6.

17. Choi B. B. Radiologic findings of lobular carcinoma in situ: mammography and ultrasonography / B. B. Choi, S. H. Kim, C. S. Park // J. Clin. Ultrasound. -2011. - Vol. 39. №2. - P. 59-63. doi: 10.1002/jcu.20772.

18. Elliott R. Initial experience with contrast enhanced digital mammography (SenoBright) - in a comprehensive clinical breast center / R. Elliott // Journal of Cancer Therapy. - 2017. N 8. - P. 146-154. doi: 10.4236/jct.2017.82012.

19.Feng J. Addition of T2-guided optical tomography improves noncontrast breast magnetic resonance imaging diagnosis / J. Feng, J. Xu, S. Jiang // Breast Cancer Res. - 2017. - Vol.19. - P. 117. https://doi.org/10.1186/ s13058-017-0902-x

20.Jacobs L. Early Diagnosis and Treatment of Cancer. / L. Jacobs, C. A. Finlayson. // Breast Cancer. - 2010. - N 8. - P.125-139.

21.Killelea B. K. Trends and clinical implications of preoperative breast MRI in Medicare beneficiaries with breast cancer / B. K. Killelea, J. B. Long, A. B. Chagpar // Breast Cancer Res Treat. - 2013. - Vol. 141. - P. 155163. doi: 10.1007/s 10549-013-2656-1.

22. Lakhani S. R. WHO classification of tumours of the breast / Lakhani S. R., Ellis I. O., Schnitt S. J. - Lyon: IARC, 2012. - 240 p. ISBN-13 9789283224334

23.Local Tumor Staging of Breast Cancer: Digital Mammography versus Digital Mammography Plus Tomosynthesis / M. Fontaine, C. Tourasse, E. Pages [et al.] // Radiology. -
2019. - Vol. 291(3). - P. 594-603. https://doi. org/10.1148/radiol.2019182457

24. Salomon A. Betrage zur pathologie und clinic der mammkarzinome / A. Salomon // Arch kiln Chir. - 1913. - Vol. 101. - P. 573-668.

25. Uematsu T. Non-mass-like lesions on breast ultrasonography: a systematic review / $\mathrm{T}$. Uematsu // Breast Cancer. - 2012. - Vol. 19(4). - P. 295-301. doi: 10.1007/s12282-012-0364-z.

\section{MULTICENTRIC AND MULTIFOCAL BREAST CANCER DIAGNOSTICS (REVIEW AND PORTFOLIO)}

\section{V.F. Zavizion, F.I. Kulikova, N.A. Davlietova}

Breast cancer in (42-48) \% of cases is a multicentric or multifocal process. Multicentricity of the tumor is the presence of several tumor foci located in different quadrants (segments) of the breast; multifocality is the presence of several tumor foci in one square or segment.

Multifocal and multicentric cancers evidently are biologically different diseases. The importance of identifying all the foci is that with a multicentric lesion, more radical types of surgical treatment are applied. With cancer monocentricity, organ-preserving surgery is predominantly chosen, and with multicentricity - radical mastectomy. Multifocality not detected at the preoperative stage and, especially, multicentricity is the cause of relapses in more than $40 \%$ of cases.

The purpose of the review is to consider the information content and effectiveness of radiation diagnostic technologies in the aspect of identification of multicentric and multifocal breast cancer.

$\mathrm{X}$-ray mammography, full-format digital Xray mammography, magnetic resonance imaging, multispiral computed tomography, infrared thermography of transmission optical tomography, sonography, digital tomosynthesis, mammoscintigraphy, electric impedance mammography are considered.

Key words: multifocal and multicentric cancer, mammography, magnetic resonance mammography, multispiral computer tomography, mammoscintigraphy, sonography, electric impedance mammography. 


\section{ДІАГНОСТИКА \\ МУЛЬТИЦЕНТРИЧНОГО \\ І МУЛЬТИФОКАЛЬНОГО РАКУ \\ МОЛОЧНОЇ ЗАЛОЗИ \\ (ОГЛЯД І ПОРТФОЛІО)}

\author{
В.Ф. Завізіон, Ф.Й. Куликова, \\ Н.О. Давлєтова
}

Рак молочної залози в (42-48) \% спостережень $є$ мультицентричним або мультифокальним процесом. Мультицентричність пухлини - наявність декількох пухлинних вогнищ, розташованих у різних квадрантах (сегментах) молочної залози; мультифокальність - наявність декількох пухлинних вогнищ в одному квадраті або сегменті.

Мультифокальні і мультицентричні раки, мабуть, є біологічно різними захворюваннями. Важливість виявлення всіх вогнищ полягає в тому, що при мультицентричному ураженні застосовуються більш радикальні види хірургічного лікування. При моноцентричності раку вибирають переважно органозберігаючу операцію, а при мультицентричності - радикальну мастектомію. Мультифокальність i, особливо, мультицентричність, що не виявлена на передопераційному етапі, $\epsilon$ причиною рецидивів більш ніж в $40 \%$ випадків.

Мета огляду - розгляд інформативності та ефективності технологій променевої діагностики в аспекті ідентифікації мультицентричного і мультифокального раку молочної залози.

Розглянуто рентгенівська мамографія, повноформатна цифрова рентгеномамографія, магнітно-резонансна томографія, мультиспіральна комп'ютерна томографія, інфрачервона термографія, трансмісійна оптична томографія, ехографія, цифровий томосинтез, мамосцинтіграфія, електроімпедансна мамографія.

Ключові слова: мультифокальний і мультицентричний рак, мамографія, магнітнорезонансна мамографія, мультиспіральна комп'ютерна томографія, мамосцинтиграфія, ехографія, електроімпедансна мамографія.

\section{ДИАГНОСТИКА МУЛЬТИЦЕНТРИЧЕСКОГО И МУЛЬТИФОКАЛЬНОГО РАКА МОЛОЧНОЙ ЖЕЛЕЗЫ (ОБЗОР И ПОРТФОЛИО)}

\author{
В.Ф. Завизион, Ф.И. Куликова, \\ Н.А. Давлетова
}

Рак молочной железы в (42-48) \% наблюдений является мультицентричным или мультифокальным процессом. Мультицентричность опухоли - наличие нескольких опухолевых очагов, расположенных в различных квадрантах (сегментах) молочной железы; мультифокальность - наличие нескольких опухолевых очагов в одном квадрате или сегменте. Мультифокальные и мультицентрические раки, повидимому, являются биологически различными заболеваниями. Важность выявления всех очагов заключается в том, что при мультицентрическом поражении применяются более радикальные виды хирургического лечения. При моноцентричности рака выбирают преимущественно органосохраняющую операцию, а при мультицентричности - радикальную мастэктомию. Не выявленная на предоперационном этапе мультифокальность и особенно мультицентричность являются причиной рецидивов более чем в $40 \%$ случаев.

Цель обзора - рассмотрение информативности и эффективности технологий лучевой диагностики в аспекте идентификации мультицентрического и мультифокального рака молочной железы.

Рассмотрены рентгеновская маммография, полноформатная цифровая рентгенмаммография, магнитно - резонансная томография, мультиспиральная компьютерная томография, инфракрасная термография трансмиссионной оптической томографии, эхография, цифровой томосинтез, маммосцинтиграфия, электроимпедансная томография.

Ключевые слова: мультифокальный и мультицентрический рак, маммография, магнитно-резонансная маммография, мультиспиральная компьютерная томография, маммосцинтиграфия, эхография. электроимпедансная томография. 